\title{
Retraction Note to: Normal families and asymptotic behaviors for solutions of certain Laplace equations
}

\section{Zhenhai Yan ${ }^{1}$ and Beatriz Ychussie ${ }^{2^{*}}$}

The original article can be found online at https://doi.org/10.1186/ s13662-015-0564-X

*Correspondence: ychussie.b@gmail.com

${ }_{2}^{2}$ Mathematics Institute, Roskilde University, Roskilde, Denmark Full list of author information is available at the end of the article

\section{Retraction}

The Editors-in-Chief have retracted this article [1] because it shows significant overlap with an article by different authors that was simultaneously under consideration with another journal [2] and with a previously published article by another group of different authors [3]. In addition, the identity of the corresponding author could not be verified: Roskilde University confirmed that Beatriz Ychussie was never affiliated to this institution. The authors have not responded to any correspondence about this retraction.

\section{Author details}

${ }^{1}$ School of Mathematics and Statistics, Central South University, Changsha, China. ${ }^{2}$ Mathematics Institute, Roskilde University, Roskilde, Denmark.

\section{Publisher's Note}

Springer Nature remains neutral with regard to jurisdictional claims in published maps and institutional affiliations.

Published online: 04 February 2020

\section{References}

1. Yan, Z., Ychussie, B.: Normal families and asymptotic behaviors for solutions of certain Laplace equations. Adv. Differ. Equ. 2015, 226 (2015). https://doi.org/10.1186/s13662-015-0564-x

2. Sun, J., He, B., Peixoto-de-Büyükkurt, C.: Growth properties at infinity for solutions of modified Laplace equations. J. Inequal. Appl. 2015, 256 (2015). https://doi.org/10.1186/s13660-015-0777-2

3. Qi, J., Zhu, T.: Some normal criteria about shared values with their multiplicity zeros. Abstr. Appl. Anal. 2010, Article ID 147878 (2010). https://doi.org/10.1155/2010/147878

\section{Springer}

(c) The Author(s) 2020. This article is licensed under a Creative Commons Attribution 4.0 International License, which permits use, sharing, adaptation, distribution and reproduction in any medium or format, as long as you give appropriate credit to the original author(s) and the source, provide a link to the Creative Commons licence, and indicate if changes were made. The images or other third party material in this article are included in the article's Creative Commons licence, unless indicated otherwise in a credit line to the material. If material is not included in the article's Creative Commons licence and your intended use is not permitted by statutory regulation or exceeds the permitted use, you will need to obtain permission directly from the copyright holder. To view a copy of this licence, visit http://creativecommons.org/licenses/by/4.0/. 